\title{
Intermédialités
}

Histoire et théorie des arts, des lettres et des techniques

Intermediality

History and Theory of the Arts, Literature and Technologies

\section{The Hermeneutics of Transmission: Deciphering Discourses on Poetry and the Arts in Early Modern Europe (1500-1800)}

\section{Déborah Blocker}

Numéro 5, printemps 2005

Transmettre

Transmitting

URI : https://id.erudit.org/iderudit/1005491ar

DOI : https://doi.org/10.7202/1005491ar

Aller au sommaire du numéro

Éditeur(s)

Centre de recherche sur l'intermédialité

ISSN

1705-8546 (imprimé)

1920-3136 (numérique)

Découvrir la revue

Citer cet article

Blocker, D. (2005). The Hermeneutics of Transmission: Deciphering Discourses on Poetry and the Arts in Early Modern Europe (1500-1800). Intermédialités /

Intermediality, (5), 37-60. https://doi.org/10.7202/1005491ar
Résumé de l'article

Cet article envisage différentes manières de rendre compte de la constitution, de la circulation et de l'institutionnalisation des discours sur la poésie et les arts dans l'Europe de l'époque moderne. Pointant quelques inconséquences dans la manière dont l'histoire des idées a traditionnellement rendu compte de l'émergence de ces discours, l'auteur examine l'utilité des techniques de la bibliographie matérielle pour la conduite d'une telle enquête. Un exemple illustre néanmoins les désavantages des études qui ne se fondraient que sur l'histoire du livre et permet à l'auteur de plaider en faveur d'études de cas conduites avec les outils de l'histoire sociale, politique et culturelle. L'article suggère enfin que, pour qui serait soucieux, en matière d'histoire des pratiques esthétiques, de dépasser les impasses de la Begriffsgeschichte, l'étude des traditions et des « actions de transmission " qui les matérialisent et infléchissent peut se révéler une perspective précieuse. 


\title{
The Hermeneutics of Transmission: Deciphering Discourses on Poetry and the Arts in Early Modern Europe $(1500-1800)^{*}$
}

\author{
DÉBORAH Blocker
}

o label is ever neutral or devoid of potential anachronisms. But some words probably do convey a smaller number of preconceived ideas than others. Hence the choice of the terms "discourses on poetry and the arts," through which I wish to point in this article to what was in many ways a new and important social and cultural phenomenon, developing throughout western Europe at various rhythms and along sometimes curious geographical patterns, between 1500 and 1800 . This phenomenon would be the emergence, dissemination and, more often than not, institutionalization of various types of wording, reasoning, and discursive practices designed specifically to define and evaluate works produced in the sphere of letters and that of the arts.

These "discourses" usually relied heavily, though not exclusively, on a series of authoritative classical texts such as Aristotle's Poetics, Horace's Art of Poetry or pseudo-Longinus' treatise On the Sublime, some of which (especially Aristotle's reflections on poetry and pseudo-Longinus' dissertation on sublime elocution) actually only became authoritative in the time span I have chosen

* This article synthesizes two recent lectures. The first one took place in January 2004 and was delivered at the University of Pittsburgh. The second one was presented in February 2005 in front of the Department of French of the University of California Berkeley. I would like to thank colleagues at both institutions for their remarks. 
to investigate. During the 16th century, Aristotle's Poetics drew the attention of Italian poets and academics (logicians, rhetoricians, moral and political philosophers, but also doctors) and their various interests in it contributed to establishing the treatise as a legitimate part of Aristotle's legacy. This complex process fostered the birth of new ways of thinking about objects that had until then remained at the periphery of scholarly inquiries, and were also largely foreign to the interests of the upper-classes in early modern societies, courtiers and merchants alike. Quickly incorporating both social or political preoccupations and many of the different fields of inquiry then captivating humanist scholarship, these discourses progressively became a specific type of knowledge or know-how (savoir-faire), at the crossroads of rhetoric, grammar, moral and political philosophy, medicine and the practices of theatrical performance. As these new preoccupations spread, they very soon crossed the frontiers of Academia to become a central element in the debates and practices of courtiers and, in some cases, of an urban elite composed of men and women of letters, artists and dramatists. In Italy, this was the case very early on, as the poetical theorizations of Giambattista Giraldi Cinzio at the Ferrarese court in the $15400^{1}$ and the debates around Guarini's Pastor Fido, which traveled from Ferrare to Venice, roughly fifty years later ${ }^{2}$, can testify. This tendency became the norm in $17^{\text {th }}$ century France, with the quarrels over Jean-Louis Guez de Balzac's prose Letters (1624), Corneille's tragicomedy Le Cid (1637), Molière's play L'école des femmes (1662-1663) or Madame de Lafayette's novella, La princesse de Clèves (1678). These quarrels played a crucial role in shaping the discourses of an informed "public," as Hélène Merlin has very clearly shown in her book, Public et littérature en France au XVII siècle. ${ }^{3}$ The spreading of scholarly discourses on

1. See Daniel Javitch, "The Emergence of Poetic Genre Theory in the Sixteenth Century," Modern Language Quarterly, Vol. 59, No. 2, June 1998, p. 140-169 and "Selfjustifying Norms in the Genre Theories of Italian Renaissance Poets," Philological Quarterly, Vol. 67, No. 1, Winter 1988, p. 196-217.

2. See Déborah Blocker, "Jean Chapelain et les 'lumières de Padoue’: l'héritage italien dans les querelles françaises sur l'utilité du théâtre (1585-1640)," Littératures classiques, No. 37, 1999, p. 97-116 and "La question des 'mœurs' dans le Pastor Fido et sa querelle," paper presented in April 2002 at the Centre d'études supérieures de la Renaissance (Tours, France) at a conference devoted to Éthiques et formes littéraires et artistiques à la Renaissance (proceedings edited by Bruno Méniel forthcoming at Éditions Honoré Champion, Paris).

3. Hélène Merlin, Public et littérature en France au XVII e siècle, Paris, Éditions Les Belles Lettres, coll. "Histoire," 1994. 
poetry and the arts to non-academic settings (and the in-depth reformulation they underwent in the process) continued throughout much of the 18th century, as debates as widespread as the one on the notion of taste can testify. It is important to note, however, that-at least where the universities where not being overshadowed by Jesuit and Oratorian collèges, as they were in France-, scholarly inquiries continued within their own traditions, while often incorporating much of what was discussed in non-academic circles. A particularly interesting case of this is the development of "aesthetics" in the 18th and 19th centuries in Germany, where the speculations of professional philosophers such as Alexander Gottlieb Baumgarten, Immanuel Kant or George Wilhelm Friedrich Hegel mingled scholarly traditions and contemporary debates, as is evident in the attention given both to taste and to the sublime in the first part of Kant's Critique of Judgment (1790).

The present article discusses how the constitution, circulation and institutionalization of these discourses on poetry and the arts in early modern Europe could best be accounted for from a historical point of view.

\section{SOME PROBLEMS WITH THE EXISTING HISTORIES of “Literary CRIticism” or “aesthetics”}

When one looks into what has been written on the history of discourses on poetry and the arts in early modern Europe, two main fields of inquiry emerge: the study of "literary theory" as it is deemed to have appeared in the Italian Renaissance, and the study of "aesthetics" as it is generally seen to have developed in Germany since the late 1700s. However, the ways in which these two strains of inquiry crystallized (and continue to be practiced), raise both theoretical problems and methodological (or practical) ones.

The theoretical problems appear to be very similar in both strains of inquiry, and when one works at the intersection of both fields, as I am attempting to do, they seem, oddly enough, to mirror each other in a rather unsettling symmetry.

The enthusiasm for what was soon labeled as "literary criticism" in the Italian Renaissance began in America. The American professor, poet, publisher and political activist Joel Elias Spingarn first published A History of Literary Criticism in the Renaissance in 1899. Spingarn's work was republished at least five times (the last one in 1976) and was followed by the works of Bernard Weinberg and Baxter Hathaway, who both produced books on a very similar 
topic in the early 1960s. ${ }^{4}$ These extremely well documented works kindled the interest of classicists and medievalists for "poetics." In 1974, Hardison, Kerrane and Preminger published an anthology of Classical and Medieval Literary Criticism $^{5}$ and, eight years later, Judson Boyce Allen published a truly groundbreaking book, entitled The Ethical Poetic of the Later Middle Ages. ${ }^{6}$ Allen's book began with an enlightening critique of the tradition he, just as much as Weinberg or Hathaway, were coming out of: New Criticism. In particular, while setting "ethics" at the center of his own quest, Allen was the first to stress that applying modern conceptions of "literature" to the textual and theoretical productions of a time where no such idea existed was bound to be counterproductive.

Indeed, the entire tradition preceding Allen's book presupposes not only the existence of such a thing as "literature," but also the timeless reality of what we now call "literary criticism." While these scholars remained focused on the Middle Ages and the Italian Renaissance, what they were actually looking for was the "ideas" they assumed constituted the seminal grounds for their own practice as contemporary "literary critics." Hence the major theoretical problem with these studies was that they imposed an "aesthetic" reading on texts that generally display a vision of the practices we now call "art" that belongs to an entirely different paradigm.

The French philosopher Jacques Rancière recently set forth a productive distinction between what he calls two "régimes" or conceptions of artistic production (and reception). ${ }^{7}$ Using both historical criteria and theoretical categories,

4. See Joel Elias Spingarn, A History of Literary Criticism in the Renaissance, NewYork, published for Columbia University Press by Macmillan, 1899 (reprinted in 1908, 1912, 1924, 1963 and 1976); Bernard Weinberg, A History of Literary Criticism in the Italian Renaissance, Chicago, Chicago University Press, 1961, 2 vol. and Baxter Hathaway, The Age of Criticism: the Late Renaissance in Italy, Ithaca, Cornell University Press, 1962.

5. O. B. Hardison Jr., Kevin Kerrane and Alex Preminger (eds.), Classical and Medieval Literary Criticism: Translations and Interpretations, New York, Frederick Ungar Publishing Corporation, 1974.

6. Judson Boyce Allen, The Ethical Poetic of the Later Middle Ages: A Decorum of Convenient Distinction, Toronto, Buffalo, University of Toronto Press, 1982.

7. See Jacques Rancière, La parole muette. Essai sur les contradictions de la littérature, Paris, Éditions Hachette, 1998; Le partage du sensible. Esthétique et politique, Paris, Éditions La Fabrique, 2000 and Malaise dans l'esthétique, Paris, Éditions Galilée, coll. "La philosophie en effet," 2004. 
Rancière contrasts a "representative regime" of the arts with an "aesthetic" one. A regime of representation would be a conception of the arts centered on mimesis. It carries with it a understanding of the arts as codified practices, in a social and political context which attributes to them ethical aims, defined as central to their legitimacy. An aesthetic conception of "art," on the other hand, is one in which the arts are defined as autonomous practices. It stresses the absence of rules and defines art as a product of sensitivity, aiming only at the production of a specific type of "aesthetic" emotion. In Rancière's understanding, "representation" defines a conception of artistic practice that was dominant from Antiquity to the 19th century, whereas the "aesthetic" regime dominates our modernity.

There are many problems with the way Rancière opposes these two "régimes." One of the most central ones is the question of the status of his own discourse, namely: is it history or myth? Jacques Rancière vehemently attacks "la nouvelle histoire" in his book Les noms de l'histoire, accusing the historians of the school of les Annales of having attempted to do away with what he feels is the defining element of historical discourse, by which he means: the story. The book ends with the claim that modern historiography - in order to truly become the history that, according to Rancière, our democratic societies so badly need-must essentially reinvent new forms of storytelling. ${ }^{8}$ One could argue that, in the case of the history of aesthetic discourse, Rancière got tired of waiting for something he probably knew all along would never happen and started producing himself the type of "récit" he was calling for. The form of storytelling he eventually come up with has more to do with myths à la Platon or à la Vico than with any kind of current historiography. In particular, his uses of textual sources can be very puzzling for historians. But, much like Plato or Vico, his myths have an exceptional heuristic value. Hence my desire to use them as a starting pointand my sometimes misguided attempts to reintroduce historical sources and/or facts into them.

One particularly helpful element of Rancière's presentation, however, is that although it is clear that in his mind the "aesthetic regime" is a product of our modernity, he insists that the two antithetical regimes he describes often coexist in contemporary conceptions of art, where their constant juxtaposition produces both tensions and misunderstandings. The works of Spingarn, Weinberg

8. Jacques Rancière, Les noms de l'histoire: essais de poétique du savoir, Paris, Éditions du Seuil, coll. "La librairie du Xx ${ }^{\mathrm{e}}$ siècle," 1992, p. 207-208. 
or Hathaway appear to embody this confusion -, a state of affairs with some dire consequences. A particularly paradoxical one is that, because these critics assume that early modern discourses on poetry and the arts are no different in status than their own theoretical reflections on "literature," their historical inquiries provide us with no way of understanding how theories of "art" imbedded in a "regime of representation" could have, as the case may be, acted as a cradle for the rise of "aesthetics." What is lost here is any sense of the historicity of this major transformation.

Conversely, historians and theoreticians of "aesthetics," at least those who are active on the French intellectual scene, such as Philippe Lacoue-Labarthe, Jean-Luc Nancy, or the late Rainer Rochlitz, are generally interested mainly in the rise of aesthetic discourses during the German Aufklärung. ${ }^{9}$ They study their development in the age of German romanticism (in groups such as the Athenaeum), their systematization under the impetus of Hegel and their reformulation (or even disintegration) during the course of our modernity, in the theoretical reflections of Schopenhauer, Nietzsche or Walter Benjamin. As philosophers, these scholars work from within the framework of German aesthetics. Thus such questions as how, when and why do the practices we have come to call "art" become a philosophical problem are also rarely asked, because it is implicitly assumed that this could only have happened in Germany at the end of 18th century. The focus is mainly on reconstituting these aesthetical debates, while the often implicit aim of these inquiries seems to be to determine and defend a status for "aesthetics" within the realm of contemporary philosophy. Thus, in the same way those who research "literary criticism" in the Italian Renaissance forget that their objects of inquiry only came into theoretical existence with the rise of the "aesthetical paradigm," the works of those who study aesthetics within the German tradition fail to fully acknowledge that the problems they are dealing with were not invented ex nihilo by Novalis or Schlegel.

From a methodological (or practical) point of view, these two fields of study also raise major problems. As they have been defined by historians of "criticism" or "philosophy", they are centered mainly, if not exclusively, on "theories" and

9. See Philippe Lacoue-Labarthe, Jean-Luc Nancy, L'absolu littéraire: théorie de la littérature du romantisme allemand, Paris, Éditions du Seuil, coll. "Poétique," 1978; Philippe Lacoue-Labarthe et al., Du sublime, Paris, Éditions Belin, 1988 and Rainer Rochlitz, Le désenchantement de l'art: la philosophie de Walter Benjamin, Paris, Éditions Gallimard, coll. "nrf/essais," 1992. 
"ideas." However, the research protocols developed by "historians of ideas" are extremely vulnerable to reservations of the sort currently voiced by many cultural historians. Most of them do not see how one can find "ideas" in archival material or in texts of any sort, without performing upon the "words" found there in operations of isolation and/or reformulation which immediately transform them into ahistorical categories carrying a strong potential for anachronism. ${ }^{10}$ The instances of the word "power," as they may appear in historical sources, are "utterances," not "ideas" of the type Plato claimed exist in the realm of the intellect: they were pronounced in specific contexts and for specific reasons. Hence, as they appear to us, they are always embedded in actions and practices that, no matter what Quentin Skinner would like to have us believe, cannot effectively be analyzed solely as "ideas" set in various discursive contexts. ${ }^{11}$ This particular problem led many of the historians who took part in

10. Anachronisms, it is important to remember, are a specifically modern problem. From the beginning of the Hellenistic period up until the very end of the Renaissance, classical texts, such as Aristotle's Poetics, were basically treated as contemporary material. But the quarrels of the Ancients and the Moderns have more often than not made this "contemporaneity" practically impossible for us today. For a discussion of these problems, see Joan DeJean, Ancients Against Moderns: Culture Wars and the Making of a Fin de Siècle, Chicago, University of Chicago Press, 1997; Marc Fumaroli, "Les abeilles et les araignées," an essay published as a preface to La Querelle des Anciens et des Modernes, $\mathrm{XVII}{ }^{e}$-XVIII ${ }^{e}$, texts established and annotated by Anne-Marie Lecoq, with a postface by Robert Armogathe, Paris, Éditions Gallimard, coll. "Folio classique," 2001, p. 7-218; François Hartog, Régimes d'historicité: présentisme et expériences du temps, Paris, Éditions du Seuil, 2003 and Levent Yilmaz, Le temps moderne: variations sur les Anciens et les contemporains, Paris, Éditions Gallimard, coll. "nrf/essais," 2004. However, the specifically modern concern with timeliness (and thus also untimeliness, as defined by Nietzsche and Benjamin) should not obscure the fact that intentional anachronisms, framed as hermeneutic practices, remain commonly mobilized in our modernity. In his book L'écriture de l'histoire (Paris, Éditions Gallimard, coll. "Bibliothèque des histoires," 1975), Michel de Certeau for instance calls both for forms of historiography that take into account the time and space occupied by the historian ("L'opération historiographique," p. 63-122) and investigates the historiographical uses of Freud's psychoanalytic theories ("Ce que Freud fait de l'histoire: à propos de 'Une névrose démoniaque au XvII siècle'," p. 291-311).

11. On "contextualisation" as it is practiced by Quentin Skinner and his followers, see Richard Rorty, J. B. Schneewind and Quentin Skinner (eds.), Philosophy in History: Essays on the Historiography of Philosophy, "Ideas in Context," Cambridge, New York, 
development of microhistory in Italy and in France in the last twenty-five years to conclude that all they could actually ever hope to do was to reconstruct what such "words" or "concepts" could have meant, when they were pointed to by an individual or, at most, a group of individuals in a specific time, place and practical setting. "Ideas," they claim, or, rather, the discourses which phrase them, can not effectively be elucidated without consideration for the actions in which they were originally mobilized.

While agreeing generally with this position, I would like to add to it a remark that pertains particularly to the type of phenomena I am currently studying, namely that what we now view as "theories" or "ideas" seem to me to have had a different status in early modern Europe, where the words "doctrine" or even "art" (meaning know-how) are far more common. Hence, by presupposing that we are dealing with "ideas" as we now see them, we would be missing one of the most interesting questions this type of analysis calls forth, that is: how is it that such "discourses" came to gain, socially and culturally, the status of "ideas"? A helpful bit of evidence as to why our modern understanding of an "idea" would be so anachronistic as far as early modern "texts" and discursive practices are concerned can be found in Antoine Furetière's Dictionnaire universel, published in Paris in 1690. This dictionary defines an idea as "[une] représentation qui se fait à l'esprit de quelque chose qui a autrefois passé par les sens," using several examples taken from Descartes' Méditations as illustrations of this primary meaning. ${ }^{12}$ This is a far cry from what is meant by the word

Cambridge University Press, 1984 and James Tully (ed.), Meaning and Context: Quentin Skinner and his Critics, Princeton, Princeton University Press, 1988.

12. This is, by no means, the end of the story, however. Within theoretical and philosophical discourse, in the 17th century, the very meaning of the terms "representation," "esprit," "mens," "sens," "sense," "signe," "nota," "idée," and the like, are very heavily contested. Hence, although there is certainly no move in the 17th century towards a Hegelian conception of the "idea," it would be misleading to see Hobbes and Locke, for example, to be taking themselves merely to be using ordinary language or to be repeating a commonplace when they make their extensive arguments that ideas are the traces of matter in motion impacting the organs of sense or that sensation is the origin of all our ideas. The same is true of Leibniz in his Quid sit idea, when he writes that "by the term idea we understand something which is in our mind [...] and the mind is something other than the brain." (see "Quid sit idea," in Gottfried-Wilhelm Leibniz, Recherches générales sur l'analyse des notions et des vérités, introduction and notes by Jean-Baptiste Rauzy, trans. Emmanuel Cattin, Laurent Clauzade, Frédéric de Buzon et 
"idea" in the locution "history of ideas." These terms commonly point to a Hegelian understanding of the concept of "idea," one where ideas are seen as spiritual entities living, as it where, a life of their own, for the most part independently of material culture. And, indeed, Begriffsgeschichte is a 19th century invention, first developed in German universities where Hegel's followers were numerous and Hegelian paradigms were strong. ${ }^{13}$ Hence the assumptions which normally guide it: the presupposition that ideas are what lead the world, the conception that men's actions are governed by these ideas - that is, essentially, that men act rationally - , or the claim that the evolution of ideas - and, indeed, history in general - can (and even should) be read in terms of progress, in other words, in teleological terms. This understanding of an "idea” not only is vulnerable to the criticisms that cultural and material historians have been developing of it ever since Marx produced his systematic undermining of Hegelianism; it is also particularly ill-suited to the analysis of cultural and intellectual trends in the early modern period. This is so, first and foremost because it is highly likely that no social agent, at the time, ever acted with, in mind, such a representation of an "idea." Hence my own strong desire to examine these trends in accordance with the words that early modern societies used to designate their own intellectual practices, - in terms of "tradition" and "transmission."

A tradition, in early modern terms, is arguably the very antithesis of what our modernity calls an "idea." The Latin verb tradere means to hand (down) to, and, in Quintilian, the noun traditio means what is received through an action of transmission, for instance, through the words of a teacher. The term

al., Paris, Presses universitaires de France, coll. "Epiméthée," 1998) Along these lines one should also consider, as a counterpoint to Antoine Furetière's definition, the terms used by the Dictionnaire de L'Académie française (first published in 1694) in which the word "idea" is defined as follows: "La notion, \& l'image que l'esprit se forme de quelque chose [...], il se prend aussi, en parlant de Dieu, pour les formes, les exemplaires, les modelles éternels de toutes les choses créées qui sont en Dieu [...], il se prend quelquefois pour les images qui sont dans la mémoire, ou dans l'imagination [...], il prend aussi figurément pour des visions chimériques ou pour des choses qui ne sont point effectives $[\ldots]$ "

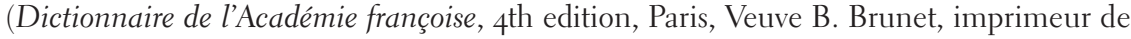
l'Académie françoise, 1762 , entry "idée").

13. And today, of course, Begriffsgeschichte continues to thrive in those very same universities which are still overwhelmingly populated by similar Hegelians. 
"transmission" itself comes from the past participle of the verb transmittere, which means more or less the same thing: to pass something (down) into the hands of others. In the early modern French dictionary that was mentioned above, Furetière's Dictionnaire universel, the word has two meanings. In legal context, it means what is transmitted: for instance a sales contract implies the "tradition" of an object to the buyer. But Furetière is quick to point out a "spiritual" meaning: "[tradition] se dit aussi en choses spirituelles, de loix, de la doctrine, des histoires que nous avons receues des mains de nos peres et qui ne sont pas escrites." A tradition, as Furetière sees it, is something that does not have a discursive existence in the form of a stabilized text: it is something that one may talk about, invoke, act according to or even against. But if traditions are indeed these often unformulated, yet highly authoritative, structurations of thought and action, it would be safe to assume that individual actors could never be absolutely sure of what a particular tradition entails (hence quarrels on the interpretation of traditions), nor, for that matter, of how it came into being. Modern reference dictionaries of the English tongue therefore very sensibly use "beliefs" or "customs" as synonyms for "tradition," thus pointing to intellectual or cultural habits one might very well mobilize and/or transmit to others without ever rationally reflecting on what one is doing. Hence the assumption of many of the most prominent cultural historians of the past century-such, for instance, as Aby Warburg ${ }^{14}$-that traditions are cultural structurations of an immaterial sort that can only be reconstituted historically through the traces left by the actions and/or appropriations of individual agents.

"Appropriation" is a concept that has been used by cultural historians such as Roger Chartier and Daniel Roche for several decades now and it probably needs no explaining. The same may not be entirely true of the concept of "action" which I have now used repeatedly throughout this article. Most of the time, I use it as an equivalent for the French word opération, as it was used, for instance, by Michel Foucault - when he studies, in Les mots et les choses (1966),

14. See for instance, Aby Warburg, Gesammelte Schriften, Leipzig, Berlin, Benedictus Gotthelf Teubner, 1932; The Renewal of Pagan Antiquity: Contributions to the Cultural History of the European Renaissance, Los Angeles, California, Getty Research Institute for the History of Art and the Humanities, 1999 and Der Bilderatlas Mnemosyne, Berlin, Akademie Verlag, 2000. For a discussion of Warburg's historiographical practices, see Georges Didi-Huberman, L'image survivante: histoire de l'art et temps des fantômes selon Aby Warburg, Paris, Éditions de Minuit, coll. "Paradoxe," 2002. 
epistemological shifts he characterizes as "opérations discursives" - or as it was mobilized by Michel de Certeau in his essay entitled "L'opération historiographique," first published in 1974. But sometimes I also use it in a slightly different meaning, which I owe to the collective efforts of the scholars with whom I work as a member of the Groupe de recherches interdisciplinaires sur l'histoire du littéraire. ${ }^{15}$ In the last three years, this research group has been attempting to study various types of early modern writing as actions, following the example set by Christian Jouhaud in his work on "les mazarinades." ${ }^{16}$ One of the main advantages of such a perspective is to allow the researcher to consider the production of texts as one of the means by which individuals attempt to act upon their social surroundings, thus making the production of writing comparable to, or at least commensurable with, other types of actions. In the case of my work on the development of discourses on poetry and the arts, this has proven particularly helpful because it allows me to study "actions of transmission" as a continuum that stretches from the production of erudite editions or commentaries to the more mundane, and, for the most part, unwritten uses of these discourses in non-academic circles, without giving precedence to certain types of actions over others. Indeed, by "actions of transmission" I mean any identifiable attempt to rephrase, reshape and/or circulate discourses of the type that interest me. And because, as James Chandler, Arnold Davidson and Adrian Johns collectively insist-in the introduction of a recent issue of Critical Inquiry ${ }^{17}$ devoted to "Arts of transmission"-, “[...] what we know depends on the practices of communication by which the knowledge comes to us," my main purpose in identifying these "actions of transmission" is, as my project develops, to locate and describe the shifts that each of these actions produces in the contents and status of the knowledge or know-how being transmitted.

But where should one search for such actions and how should one go about tracking them down? The second half of this article will attempt to address these practical questions.

15. For details, see their website: <http://www.ehess.fr/centres/grihl/index.html>.

16. Christian Jouhaud, Mazarinades: la fronde des mots, Paris, Aubier, coll. "Collection historique," 1985.

17. James Chandler, Arnold Davidson and Adrian Johns, Arts of Transmission: An Introduction, Critical Inquiry, Vol. 31, No. 1, "Arts of transmission," Fall 2004, p. 1-7. 


\section{“Manières de faire"}

When I first started studying the transmission of Aristotle's Poetics, two years ago, I had little or no idea what I was doing. Whatever research techniques I have developed and am still developing, as the project expands, are therefore the result of a continuous (and continuing) process of trial and error. However, because I aimed first and foremost to avoid the traditional routines of historians of ideas, I have in the process become what many people would call a staunch materialist. That is to say that, in order not to demand from my sources more than they actually have to offer, I have centered my research on the specific types of traces with which libraries and archives furnish us most abundantly, namely books and biographical elements of the lives of individuals.

Somehow, I instinctively-and rather naively-trusted books, in their materiality, to give me a much more accurate picture of the circulation of discourses on poetry and the arts than the disembodied summaries available in the above-mentioned secondary literature. So one day, while working in the Bibliothèque nationale in Paris, I found myself making a lengthy chronological list of all of the editions of Aristotle's Poetics within the Aristotelian Opera omnia. Then I meticulously asked for every complete copy of these editions the librarians would agree to show me. As I poured over them, deciphering everything from the coat of arms to the indexes, I became convinced that studying these editions as a meaningful series, or set of series, might actually be a way of paying justice to what they were, namely the materializations of actions of transmission, as well as the embodiments of many different sorts of writing, reading and collecting practices.

What was the most intriguing at first was the variety of scholarly traditions that seemed at work in the material. As I slowly completed descriptions of each individual edition, and started classifying them empirically in various types of categories, odd patterns, of which the secondary sources I had been relying on said nothing, seemed to appear. In the hope of better understanding these recurrences, I attempted to map out some of these patterns, both chronologically and geographically. While a fellow at the Warburg Institute in the spring of 2003 , I constructed the puzzling document reproduced on the adjacent page (fig. 1) under the title: "The Poetics within the complete works of Aristotle (14951668)." This document lists and classifies all the possible orders in which the Aristotelian corpus was printed in the twenty-eight editions I consulted (about three quarters of the actual production, I have calculated), all published between 
Fig. 1. The Poetics within the complete works of Aristotle (1495-1668)

\section{ORDERS OF THE PRINTED EDITIONSOF THE ARISTOTELIAN CORPUS IN EARLY MODERN EUROPE}

First possible order: Logic with Rhetoric and Poetics at the end, followed by Physics, then Metaphysics, ending with Ethics and Politics.

- [0]* ${ }^{*}, 1495^{-1498}$, Greek, Venice, Aldus Manutius, in-folio, 6 vol. (editio princeps, with neither Rhetoric nor Poetics).]

- [108.218], 1551-1553, Greek, Venice, Aldi filii, in- $8^{\circ}, 6$ vol.

- [o], 1579, Latin, Lyon, apud Iacobum Juntas, in- $8^{\circ}, 7$ vol.

- [108.664], Greek and Latin, 1584-1585, Frankfort, sons of A. Wecheli, Cl. Marinius \& Io. Aubrius, in$4^{\circ}, 10 \mathrm{vol}$.

Second possible order: Logic with Rhetoric and Poetics at the end, followed by Ethics and Politics, then Physics, ending with Metaphysics.

- [o] 1550-1552, Latin, Venice, apud Juntas, in- $4^{\circ}, 7$ vol.

- [108.193], 1550-1552, Latin, Venice, apud Juntas, in-folio, 11 vol.

- [108.423], 1560, Latin, Venice, apud Cominum Tridino, in- $8^{\circ}, 11$ vol.

- [108.456], 1562, Latin, Venice, apud Juntas, in- $8^{\circ}, 16$ parts in 12 vol.

- [o], 1562, Latin, Venice, apud Juntas, in- $8^{\circ}, 11$ parts in 13 vol.

- [108.457], 1563, Latin, Basel, Io. Hermagius, in-folio, 3 parts in 1 vol.

- [?], 1573-1575, Latin, Venice, apud Juntas, in-8 $8^{\circ}, 9$ parts plus an index in 12 vol.

- [o], 1668, Latin, Rome, Typis Angeli Bernabo, in-4 $4^{\circ}, 5$ parts in 6 vol.

Third possible order: Logic, followed by Physics, then Ethics and Politics with Rhetoric and Poetics at the end, ending with Metaphysics.

- [107.928], 1531, Greek, Basel, Io. Bebelius, in-folio, 1 vol.

- [107.968], 1538, Latin, Basel, [Io. Oporinus], in-folio, 2 vol.

- [108.033], 1542, Latin, Basel, [Io. Oporinus ?], in-folio, 3 vol.

- [108.137], 1548, Latin, Basel, Io. Oporinus, in-folio, 3 vol.

- [108.174], 1550, Greek, Basel, Io. Bebelius \& M. Isingrinius, in-folio, 1 vol.

- [108.429], 1561, Latin, Lyon, Io. Frellonius, in-folio, 1 vol.

- [108.652], 1581, Latin, Lyon, Stephanus Michaeles, in-folio, 1 vol.

- [108.708], 1590, Greek and Latin, Lyon, Guillaume Lemaire, in-folio, 2 parts in 1 vol.

- [108.755], 1597, Greek and Latin, [Geneva], Guillaume Lemaire, in- $8^{\circ}, 2$ vol.

- [o], 1605, Greek and Latin, Geneva, Petrus de la Rovière, in-folio, 2 vol.

- [0], 1607, Greek and Latin, Geneva, Petrus de la Rovière, in- $8^{\circ}, 2$ vol.

- [o], 1619, Greek and Latin, Paris, Typis Regiis, in-folio, 2 vol.

- [o], 1629, Greek and Latin, Paris, Typis Regiis, Societatis Græcorum Editionum, in-folio, 2 vol.

- [o], 1654, Greek and Latin, Paris, Jean Billaine, Simon Piget \& Frederic Leonard, in-folio, 4 vol.

Order adopted by a single portable Latin edition: Logic, with the Rhetoric and the Poetics at the end, then Physics, followed by Ethics and Politics, ending with Metaphysics.

- [o], 1584-1585, Latin, Venice, Io. Bruniolus, in-16 $6^{\circ}, 8$ vol.

Order adopted by a another single portable Latin edition: Logic, with no Rhetoric or Poetics at the end, then Physics and Metaphysics, followed by Ethics and Politics, ending with the Rhetoric and the Poetics, Problems added at the end.

- [o], 1580 (and 1608 for the Problems), Latin, [Geneva], Jacques Berjon, typographer from Lyon, in-16 7 vol. including an index.

* These parentheses list the number given in the Bibliographica Aureliana. See Ferdinand Edwarz Cranz and Charles B. Schmitt «Bibliotheca Bibliographica Aureliana ", in Ferdinand Edward Cranz, A Bibliography of Aristotle Editions, 1501-16oo, second edition with addenda and revisions by Charles. B. Schmitt, XXXVIII, Baden-Baden, 1984; [o] appears when the edition is not listed in Cranz/Schmitt. 
1495-1498 (the first Aldine edition) and 1668, at which point early modern printers basically stopped publishing such things. To make a long story short, the Poetics, a newly recovered text in the 16th century, although always published as a sequence to Aristotle's Rhetoric, rarely appears in the same place within the corpus on this list: sometimes the Rhetoric and the Poetics follow the logical texts (i.e. the so-called organon, or supposed tool kit of Aristotelian rationality) as they do in what I called the "first possible order", sometimes both texts are a prelude to the ethical and political treatises (as can be seen in the "second possible order"), and sometimes the two are published in the vicinity of the Metaphysics, which is what happens when the "third possible order" is adopted.

This clearly indicates a problematic status, as if at the time when discourses on poetry were being instituted as an academic practice, no one in Academia quite knew to which branch of knowledge these newly-born doctrines belonged. Some of the patterns I spotted also had a geographical recurrence. In particular the linking of the Rhetoric and the Poetics to the organon was the dominant tradition in Venetian printing, whereas the printing centers of northern Europe (Paris, Basel, Geneva, etc.) generally favored printing the Rhetoric and the Poetics towards the end of the corpus, more or less clearly in the vicinity of what was then considered the acme of Aristotelian philosophy, the Metaphysics.

But once I had painstakingly constructed this list, I was left wondering somewhat fruitlessly about how to interpret it. The linking of the Rhetoric and Poetics to Aristotle's organon, which can seem odd at first if one is used to deciphering the Poetics within the "aesthetic paradigm," turned out to be the easiest tradition to explain. It can be traced back to the readings of the Poetics proposed by medieval Arabic philosophers and it is well documented in recent books by Deborah Black and Salim Kemal. ${ }^{18}$ The reason this tradition is dominant in Venetian publishing throughout most of the 16th century has to do with the presence, at the Studio Padovano in the first half of the century, of doctors and logicians stemming out of Judeo-Arabic traditions, such as Abrahamo de Balmes and Jacob Mantino, whose influence on the curricula and, in this particular case, on the decisions taken by editors and printers was apparently great. ${ }^{19}$

18. See Deborah L. Black, Logic and Aristotle's Rhetoric and Poetics in Medieval Arabic Philosophy, Leiden, E. J. Brill, 1990 and Salim Kemal, The Poetics of Alfarabi and Avicenna, Leiden, E. J. Brill, 1991.

19. On Abrahamo de Balmes, see Nicola Ferorelli, "Abrahamo de Balmes ebreo di Lecce i suoi parenti," Archivio storico per le province napoletane, No. 31, 1906, p. 632-654 
But I was truly puzzled by the printing habits of Northern European publishers. Why were they consigning the Rhetoric and the Poetics to the end of the corpus? Was the vicinity of the Metaphysics a sign of neglect or a promotion? I went over the prefatory materials of each edition time and time again, looking for justifications of this peculiar order, only to discover that many of the prefaces described an ideal order of the Aristotelian corpus that often had much more to do with the description given of his philosophy in Diogenes' Lives of famous philosophers than with the actual order his texts were printed in, in the editions I was handling. This was another instance in which distinguishing "ideas," as they are voiced in "texts" from actual practices proved extremely helpful. Yet consistent recurrence suggests either rationality or habit, or both. And small clues I picked up here and there, in scattered and disorderly readings ${ }^{20}$, seemed to indicate that one needed to continue hunting for an answer. For the moment, I only have working hypothesis, which was suggested to me by a scholar named Philippe Büttgen, who currently works on early modern German philosophy, and, more particularly, on Martin Luther. ${ }^{21}$ When I described to him what I had seen in the Aristotelian Opera omnia published in Northern Europe, Philippe Büttgen reminded me that a good knowledge of Hebrew and of Hebraic scholarly traditions (including Kabbalah) was common among the scholars who strived to publish the Aristotelian corpus in Germany

and Giulio Tamani, "Le traduzioni ebraico-latine di Abrahamo de Balmes," in Angelo Vivian (ed.), Biblische und judaistische Studien. Festrichft für Paolo Sacchi, Bern, Frankfurt am Main, Las Vegas, Peter Lang Verlag, 1990, p. 613-635. On Jacob Mantino, see David Kaufmann, “Jacob Mantino: une page de l'histoire de la Renaissance," Revue des études juives, No. 27, 1893, p. 30-60 and p. 207-38.

20. For instance, Jean-Pierre de Rotschild, "La réception de la Rhétorique dans la littérature hébraïque du Moyen Âge," in Gilbert Dahan and Irène Rosier-Catach (eds.), La Rhétorique d'Aristote: traditions et commentaires de l'Antiquité au XVII siècle, Paris, Librairie philosophique Jean Vrin, 1998, p. 257-282; Allison P. Coudert, "Leibniz, Locke, Newton and the Kabbalah," in Joseph Dan (ed.), The Christian Kabbalah: Jewish Mystical Books and their Christian Interpreters, Cambridge, Harvard College Library, 1997, p. 149-180 and Giulio Busi and Elena Loewenthal (eds.), Mistica ebraica: testi della tradizione segreta del giudaismo dal 3 al 18 secolo, introduction by Giulo Busi, Torino, Giulio Einaudi Editore, 1995.

21. Philippe Büttgen is chargé de recherches at the Centre national de la recherche scientifique (CNRS) and is currently stationed in Göttingen, at the Mission historique française en Allemagne (MHFA). 
in the first half of the 16th century. Hence I now suspect that one of the reasons for the somewhat curious placement of Aristotle's Poetics in the Aristotelian corpus as it was published across Northern Europe in the 16th century (i.e. the Poetics in the close vicinity of the Metaphysics) may have something to do with the knowledge that Erasmus and Melanchton had of Hebraic mysticism, where poetry and the divine, or, rather, metaphors and metaphysics, are sometimes closely associated. This particular tradition, if it can be documented, could furnish a satisfactory answer, for instance, to the problem of the curious status of Aristotelian poetics in Baumgarten's Meditationes philosophicce de nonnullis ad poema pertinentibus (1735). ${ }^{22}$ Indeed, in Baumgarten's essay Aristotle's treatise is read both in a logical perspective and in relation to metaphysical questions. Yet there are many intellectual habits that could be involved here, such as the tradition of considering the practice of poetry as linked to the utterances of unworldly truths (Dante was seen as a theologian as much as a poet throughout the Renaissance), something that can be linked to Platonist and Neo-Platonist assumptions. My main problem however is that I have not been able to trace which group of individuals, if any, would have been responsible for the mobilization and dissemination of these habits. Hence I still doubt whether the pattern that seems to appear on this page is what I define as a "tradition" or whether the recurrences I think I see are simply leading me to hasty inferences. This is because a tradition can only be characterized as such if one can find individuals for whom it was a commonplace, people who make use of it in their actions, and who, by (re)activating it and even modifying it, make it transmissible to others. In the absence of such people, a tradition is effectively dead - and a dead tradition is hardly a tradition at all for the actors of any culture. Hence my methodological claim that traditions can only accurately be approached, from a historical point of view, through the observation and reconstruction of individual actions of transmission - which means, because of the

22. See Alexander Gottlieb Baumgarten, Meditationes philosophicce de nonnullis ad poema pertinentibus, quas ad d. (23) septembris $1735[. .$.$] dijudicationi submittit M. Alexan-$ der Gottlied Baumgarten, respondente Nathanaele Baumgarten, Halæ Magdeburgicæ, in$4^{\circ}$, [no date stated on publication except in title]. A French translation exists: Alexander Gottlieb Baumgarten, Esthétique, précédée de Méditations philosophiques sur quelques sujets se rapportant à l'essence du poème et de la Métaphysique, translation, presentation and notes by Jean-Yves Planchère, Paris, Éditions de l'Herne, coll. "Bibliothèque de philosophie et d'esthétique," 1988. 
specific nature of historical evidence, through the physical traces such actions leave in material culture. But, for the moment, in the case of the Northern editions of the Aristotelian corpus, I remain incapable of documenting the missing links.

Some of my other bibliographical lists turned out to be less puzzling than this one, but I tend to think that when one is reflecting on methodology, problems or even possible failures can actually be far more helpful than successes. In the case of my puzzling taxonomies, that is exactly what happened. First I decided to leave my unsolved enigma aside until I had the time and support needed to spend several months in one or two Northern European libraries. Soon after that, I found myself craving not so much an accurate understanding of the patterns of printed matter as a better comprehension of human behavior and the trajectories of individuals. It suddenly dawned on me that in looking for traditions, it might be better to start on a smaller scale, that is at the level of what people did with them, in specific contexts. By reversing the perspective and comparing case studies, it might be easier to understand what was a significant recurrence and what was just a set of (possibly) unfortunate inferences on my part. I did not have the proper archives at hand to set off on a case study on Baumgarten, so instead, I got to work on two other case studies, better documented in French and English libraries, one centered on Francesco Robortello (among other things, the author of the first scholarly commentary on Aristotle's Poetics ${ }^{23}$ ), and the other constructed around Nicolas Boileau-Despréaux, the poet, who, also among many other things, introduced the "sublime" into Louis the XIVth's court, in 1674.

In the latter case, it was when I stumbled on a very odd anecdote, consigned in an anonymous letter addressed to the exiled French aristocrat BussyRabutin, that I suddenly found myself yearning irrepressibly for microhistory. ${ }^{24}$

23. See Déborah Blocker, "Élucider et équivoquer: Francesco Robortello (ré)invente la catharsis," Cahiers du centre de recherches historiques, Jean-Pierre Cavaillé (ed.), "Stratégies de l'équivoque," No. 33, 2004, p. 109-140.

24. This anecdote is taken from the correspondance of Roger de Bussy-Rabutin (Correspondance avec sa famille et ses amis, 1666-1693, Ludovic Lalanne (ed.), Paris, Charpentier, 1858-1859, 6 vol., in-12, tome II, p. 415 and 416). The letter is not a letter by Bussy-Rabutin, it is addressed to him at a time when he has been exiled from the court. Also, it is not signed but Bussy-Rabutin's editor tentatively attributes it to the actress Mlle Dupré. Raymond Picard, Corpus racinianum, Paris, Bibliothèque des Belles Lettres, 
The story it tells is the following: in early January 1675, Madame de Thianges (Gabrielle de Rochechouart, sister to Madame de Montespan, Louis the XIVth's official mistress since 1667), gave the Duc du Maine (the first legitimized son of Louis the XIVth and his mistress Madame de Montespan, born in 1670) a New Year's gift (étrennes) consisting of a miniaturized room, in a box as large as a table and entirely gilded. Above the main door of the box, a sign read "Sublime chamber" and inside were a bed, a balustrade and large armchair in which a wax figurine of Monsieur du Maine, very much like himself (so the eyewitness testifies), was seated. Not far from this chair stood a similar representation of Monsieur de la Rochefoucauld (the duke François VI de La Rochefoucauld, author of a book of sententice, Les maximes, published anonymously in 1665), to whom the Duc du Maine handed a page covered with verse (the court rumors had it that he wrote verses at the age of four), so that Monsieur de la Rochefoucauld might correct them. Standing just behind the armchair, a figurine of Madame Scarron, the widow of the satirical author Scarron, who had been appointed governess of Madame de Montespan's legitimized children and had recently become the King's unofficial mistress, supervised their exchanges. Surrounding them were Monsieur de Marcillac (the eldest son of the Duc de La Rochefoucauld and then lover of Madame de Thianges) and Monsieur de Condom (alias Jacques-Bénigne Bossuet, court preacher and tutor to the King's legitimate heir, the Dauphin, since 1670). At the other end of the alcove, the figurines of Madame de Thianges and of Madame de Lafayette (the presumed author, with the Duc de la Rochefoucauld, of the novella La princesse de Clèves) read poetry together. Outside this closed perimeter, behind the balustrade, in a tableau reminiscent of the one established in the King's chambers

1956, p. 64, dates this letter from January 15, 1675 and gives the following text for it: "Madame de Thianges a donné au duc du Maine en étrennes une chambre grande comme une table toute dorée. Au dessus de la porte, il y a écrit Chambre Sublime, et dedans il y a un lit, un balustre et un grand fauteuil, dans lequel est assis M. du Maine fait en cire en petit, fort ressemblant. Auprès de lui M. de la Rochefoucauld auquel il donne des vers pour les examiner; derrière le dos du fauteuil Mme Scarron. Autour de lui le prince de Marcillac et M. de Condom; à l'autre bout de l'alcôve Mme de Thianges et Mme de Lafayette lisant des vers ensemble. Au dehors des balustres Despréaux, avec une fourche empêchant sept ou huit mauvais poètes d'approcher. Racine, auprès de Despréaux et un peu plus loin La Fontaine auquel il fait signe de la main d'approcher. Toutes ces figures sont faites en cire, en petit; et chacun de ceux qu'elles représentent a donné la sienne. On les appelle la cabale sublime." 
in Versailles during the daily courtly ritual of his grand lever and grand coucher, the poet Boileau-Despréaux, held a pitchfork, with which he was attempting to prevent seven or eight "mediocre poets" (mauvais poètes) from entering the chamber. The court dramaturge Racine stood besides Boileau and a little further off one could apparently spot La Fontaine, the author of the Fables, whom Racine was calling into the chamber with a sign of his hand. All of these little figurines were made out of wax and each of the individuals they represented had paid for the one that depicted him or her. The other courtiers, probably jealous of the intricate networks this curious doll-house displayed, nicked-named them the "cabale Sublime," probably be best translated as sublime clique, thus pointing their fingers at Madame de Montespan's group of followers, who, in the representation they had produced of themselves, had de facto excluded them. There would be many things to say about this odd New Year's gift, but I will concentrate here on the question I found the most puzzling when I first discovered this text, namely: what in the world does pseudo-Longinus' definition of the "sublime" have to do with these aristocrats and/or writers who gather in the intimacy of the King's mistresses at the opening of the year 1675 ?

The answer to this question is both long and complicated. It might be summarized as follows: Boileau published in 1674 a book entitled Euvres diverses which can be analyzed as an attempt to win the King's favors and occupy the position of poetical and political guardian of the orthodoxy of those who gravitated in the King's inner circle. The book contained, among other things, Boileau's Art poétique, a poem in four parts spelling out for would-be poets "rules" inspired mainly by Horace's Art of Poetry and Aristotle's Poetics. But the book also contained the first French translation of pseudo-Longinus' treatise On the Sublime. The first of the two texts indicated very clearly, in its fourth part, how poets could best serve the King, namely by producing orthodox poems in his Majesty's praise. Yet the presence of a translation of pseudo-Longinus' text seemed to hint to a different manner of pleasing the monarch, namely the "sublime" mode of praise, accessible only to the happy few admitted into his intimacy, where they could become the enlightened witnesses of his radiance. The doll-house given to the Duc du Maine embodies this subtle distinction between the lowly and mediocre poets that Boileau repels, armed with his sublime and distinctive pitchfork, and those who, having passed the test of sublimity, are allowed into the small court of high-ranking aristocrats and favored writers who gather around the Montespan. This courtly instrumentalization of pseudo-Longinus' treatise on poetic enthusiasm is never mentioned in the works 
that retrace the introduction of the treatise onto the French intellectual scene of the late $17^{\text {th century. }}{ }^{25}$ But once I had figured out the enigma of the "sublime chamber," many of the modes in which the text was read and commented upon between $155^{\circ}$ and 1750 became much clearer to me.

In particular, my understanding of the text's editorial history seemed much more satisfying. Once I had produced yet another analytical list of editions, I realized that many details which would otherwise have remained obscure suddenly made much greater sense. For instance, I understood far better how the text, first printed in Bale by the Italian Hellenist Francesco Robortello in 1554, had been seen as an anti-Horatian and anti-Aristotelian treatise on poetic elocution, that is as a text of an almost subversive quality-un texte pour "esprits forts," as the French would say. ${ }^{26}$ The two engravings reproduced in the neighboring pages (figs. 2-3) point to this interpretation. They are taken from an counterfeit edition of Boileau's Euvres diverses, published in Amsterdam in 1689. This edition, housed today in the collections of the Bibliothèque nationale, displays these two engravings prior to the title page. The first one is a copy of the frontispiece of the Euvres diverses published in 1674 . It shows a young man in Roman attire: Horace, Boileau - or perhaps even Louis the XIVth himself, who liked to appear in such clothes, in his youth. The character is standing in a setting that is unmistakably a jardin à la française, with a construction much like Versailles and a sort of fontaine aux Tritons in the background. He points his finger towards a small and carefully pruned orange tree (the Orangerie was one of the many luxuries of Versailles), surrounded by two gardeners. The tree is covered with fruits and the pot clearly displays the emblem of the Roi Soleil. On the lower right of the engraving, right under the pot that is attracting so much attention, one reads the words "utile dulci," a transparent allusion to the most commonly quoted verse of Horace's Art of Poetry, in which the Roman

25. See in particular Jules Brody, Boileau and Longinus, Geneva, Librairie Droz, 1958; Sophie Hache, La langue du ciel: le sublime en France au XVII ${ }^{e}$ siècle, Paris, Éditions Honoré Champion, coll. "Lumière classique," 200o; Lawrence Kerslacke, Essays on the Sublime, Bern, Peter Lang Verlag, 2000 and Nicholas Cronk, The Classical Sublime: French Neoclassicism and the Language of Litterature, Charlottesville, Rookwood Press, 2003.

26. An article by Marc Fumaroli documents this tradition, see Marc Fumaroli, "Rhétorique d'école et rhétorique d'adulte: la réception européenne du Traité du Sublime aux $\mathrm{XVI}^{\mathrm{e}}$ et $\mathrm{XVII}^{\mathrm{e}}$ siècles," reprinted in Héros et orateurs: rhétorique et dramaturgie cornéliennes, Geneva, Librairie Droz, coll. “Titre courant," 1996 [1990], p. 389-390. 

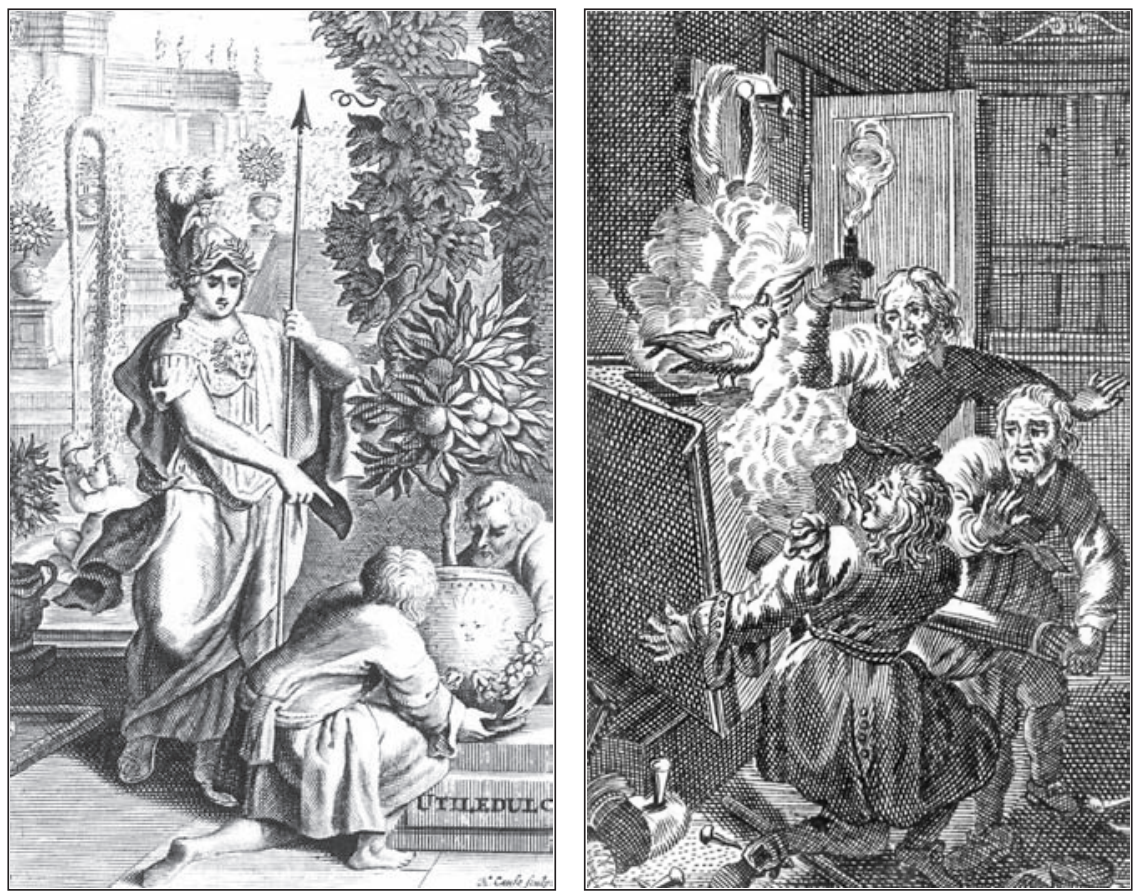

Figs. 2-3. Two frontispieces: engravings taken from Nicolas Boileau-Despréaux, Euvres diverses, in- $8^{\circ}$, Amsterdam. Abraham Wolfgang, 1689 (Bibliothèque nationale de France, Résac. X. 3078).

poet was said to encourage his fellow-writers to constantly mingle pleasure with moral instruction. Obviously, this is an allegorical representation of Horace's Art of Poetry and/or of Boileau's Art poétique. Its reprinting in the 1689 counterfeit edition of the Euvres diverses was probably intended to make clear to Dutch and European readers alike what Boileau's text owes to Horace, while also signaling to all what role the French poem was currently playing at the court of Louis the XIVth. The second engraving is entirely different and it is, to the best of my current knowledge, an invention of the Dutch printer. It pictures a dark and possibly humble interior. Three men are shown, of whom one is holding up a candle so that all can see. The two others are kneeling in front of a gigantic book in an attitude of awe, or perhaps even fear. At the top of the book, smoke is puffing out and, in it, an owl can be seen, probably a symbol of Greek wisdom, and possibly also alluding to occult practices of some sort. On the floor, on the left, there are nails and carpenter tools; on the right, 
a set of pincers. Apparently the men have just pried the book open with a metal rod. The image seems to emblematize pseudo-Longinus' treatise On the Sublime, which it portrays as a text just recently rediscovered, accessible only to the humble philologists who would be ready to force their way into this obscure, secretive and awe-inspiring discourse, in the way a handful of alchemists would be ready to collectively attempt the transformation of lead into gold. Facing each other as they do in this counterfeit edition, these two engravings adapt Boileau's enterprise to the European market: they both indicate what is at stake in his Art poétique and attract the attention of potential readers to pseudoLonginus' treatise. In many ways, they are also material representations of "actions of transmission."

This second (but certainly not secondary) aspect of my research thus hinges on case studies grounded in social, cultural and political history. These minute contextualizations are necessary because they help us understand the practical aims of the promoters and developers of discourses of poetry and the arts, be they powerful patrons, scholars, courtiers, poets, artists, publishers or merely men and women of letters. If their actions and conceptualizations are not carefully examined, their motivations in defending a specific position will always remain obscure and what I would prefer to label their "interests" will continue to appear as nothing but "ideas." This, I think, is an aim that most of the Italian founders of microhistory as historiographical practice would probably approve of. ${ }^{27} \mathrm{My}$ goal of arriving at a better understanding of a transformation or evolution that I think occurred over several centuries and was taking place all over Europe, but at different times and very different paces, throughout the early modern period, also owes much to the kind of cultural history practiced by Carlo Ginzburg. ${ }^{28}$ This is the case in particular because I believe that, in order to bypass the frontiers and chronological boundaries which have hampered the work of the historians of "poetics" in the Italian Renaissance and limited the inquiries of the historians of German "aesthetics," case studies should

27. I am thinking mainly of Edoardo Grendi, "Micro-analisi e storia sociale," Quaderni storici, No. 35, 1977, p. 506-520 and of Giovanni Levi, L'eredita immateriale. Carriera di un esorcista nel Piemonte del Seicento, Torino, Giulio Einaudi Editore, 1985.

28. See in particular Carlo Ginzburg, The Night Battles, Baltimore, Johns Hopkins University Press, 1983; History, Rhetoric, Proof, Hanover, New Hampshire, University Press of New England, 1999 and Wooden Eyes: Nine Reflections on Distance, New York, Columbia University Press, 2001. 
be used as often as possible to produce frequent variations in the scale on which research is conducted, thus allowing for the constant reframing of the objects of inquiry as well as the ruthless deconstruction of all preconceived periodizations.

In the introductory article of a collective book, Jeux d'échelles: la microanalyse à l'expérience, ${ }^{29}$ the French historian Jacques Revel reflects on this specific instrumentalization of the techniques of microhistory. Revel suggests that the practices of microhistory could actually transform our "strategies of knowledge," 30 by making it possible for historians to use case studies to reframe (or even do away with) pre-established chronologies and/or geographies. He strongly insists that the most fruitful element of "micro-analysis" was not the choice of a smaller scale in itself, but the variations in scale (and hence in understanding) that case studies and careful contextualization allowed.

As I reflect on my own research, I realize that only the recurrences in the case studies which I have conducted so far can document the transformations I am claiming took place. Moreover, only careful contextualizations, centered on a small group of individuals, have produced a better understanding of the traditions that the study of material bibliography often made manifest, but couldn't always account for. I am therefore claiming that holding, as it were, both ends of the historical chain, because it is an exercise that calls for constant reformulations and readjustments, is a way to produce a more accurate and precise genre of cultural and intellectual history than the one traditionally produced by "historians of ideas."

\section{Traditions as Historiographical Tools:}

\section{Are Transmission Studies an Emerging Field?}

But this is true first and foremost because of the specific nature of traditions. Understood as constellations of beliefs, structured by recurrent actions and yet constantly transforming themselves into new and sometimes radically different conjunctions of habits and values, traditions are neither ideal nor material, and can only be reconstituted through the careful study of what people did (and sometimes continue to do) with them.

29. Jacques Revel, Jeux d'échelles: la micro-analyse à l'expérience, Paris, Éditions Gallimard, Éditions du Seuil, coll. "Hautes études," 1996.

30. Jacques Revel, "Micro-analyse et construction du social," in Jeux d'échelles, p. 19. 
This makes them an ideal view point from which to construct and conduct new types of cultural history. In particular, studying these "actions of transmission" and making a point of deciphering the aims and the outcomes of the endless restructuring to which these actions submit all existing traditions could well become yet another way to set aside-or maybe even to overcome? - the traditional and more often than not highly dissatisfying distinction between the ideal and the material which has divided cultural studies since the invention of cultural history as an academic field of inquiry.

If this were the case, transmission studies would be on the verge of becoming an exciting new field of inquiry for historians of culture. Critical Inquiry's recent interest for the "arts of transmission," just as much as this journal's present curiosity for various forms of "transmission" could thus well be signaling the constitution of a promising subfield of cultural history. 